\title{
Intermediary Role of Ways of Coping with Stress in the Relationship between Satisfaction with Life and Motivation
}

\author{
Oznur Tulunay Ateş ${ }^{1}$ \\ 'Mehmet Akif Ersoy University, Faculty of Education, Turkey \\ Email: otates@mehmetakif.edu.tr Tel: +9005052955358
}

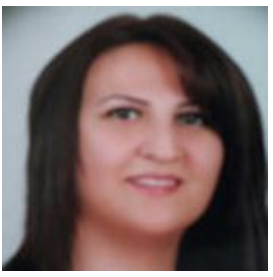

\begin{abstract}
The aim of this study is to test the theoretical model developed in relation to the intermediary role of ways of coping with stress in the relationship between satisfaction with life and motivation. The study was conducted with 568 university students; 112 female and 456 male students studying at Bartin University Faculty of Engineering. The study data was collected with Ways of Coping Scale, Adult Motivation Scale and Satisfaction with Life Scale. Descriptive statistics and correlations of the variables were examined to analyse the data. In addition, the model established for the relationships between ways of coping with stress, motivation and satisfaction with life was tested with Structural Equation Modelling (SEM). LISREL 9.30 and SPSS 24 programs were used for analyses. The results of the t-tests conducted indicate that ways of coping with stress, motivation and satisfaction with life do not vary significantly according to gender among university students. According to the correlation analysis and measurement model results; it is seen that there is a relationship between satisfaction with life, motivation and ways of coping with stress. It was seen that the structural model established in relation to the intermediary role of the ways of coping with stress variable in the relationship between satisfaction with life and motivation has good fit values and it was determined that ways of coping with stress have intermediary role in the model.
\end{abstract}

Keywords: Satisfaction with life, Motivation, Ways of coping with stress, Structural equation model, Intermediary role, University students.

Citation | Oznur Tulunay Ates (2019). Intermediary Role of Ways of Coping with Stress in the Relationship between Satisfaction with Life and Motivation. Journal of Education and e-Learning Research, 6(1): $1-9$.

History:

Received: 8 October 2018

Revised: 13 November 2018

Accepted: 19 December 2018

Published: 21 February 2019

Licensed: This work is licensed under a Creative Commons

Attribution 3.0 License (c)

Publisher: Asian Online Journal Publishing Group
Funding: This study received no specific financial support.

Competing Interests: The author declares that there are no conflicts of interests regarding the publication of this paper.

Transparency: The author confirms that the manuscript is an honest, accurate, and transparent account of the study was reported; that no vital features of the study have been omitted; and that any discrepancies from the study as planned have been explained.

Ethical: This study follows all ethical practices during writing.

\section{Contents} 1. Introduction

2. Method . .3

3. Results

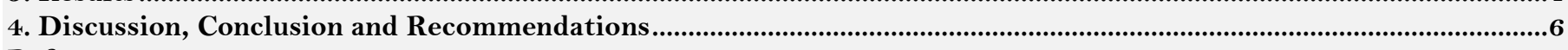

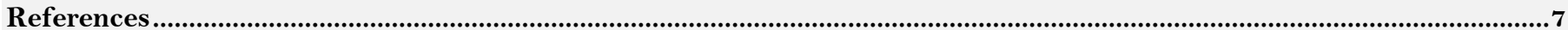




\section{Contribution of this paper to the literature}

This study contributes to the existing literature by testing the theoretical model developed in relation to the intermediary role of ways of coping with stress in the relationship between satisfaction with life and motivation.

\section{Introduction}

During university years in which work life and private life are shaped, students' need for satisfaction with life, coping with stress and motivation increases. These years in which complex emotions are felt intensively are also a critical time period in terms of the interaction between emotions, thoughts and behaviours.

For many countries, the fact that most of the students cannot complete their university education as their expectations are not met, they lack motivation and they are disappointed is a very important problem (Tinto, 1975). It may be thought that satisfaction with life is effective in such problems that university students experience. The concept of satisfaction with life was first described by Neugarten et al. (1961) as the circumstance or result that the individual obtains by comparing his expectations with what he has. The concepts which are considered as the synonyms of satisfaction with life include happiness and subjective wellbeing (Lu, 2000). Subjective wellbeing consists of three different components. These are positive affect, negative affect and satisfaction with life. Positive affect consists of liked emotions and negative affect consists of disliked emotions (Diener, 1984; Diener et al., 1999). Satisfaction with life is described as a process which includes cognitive judgments in which the individual evaluates the quality of his life within the framework of the criteria determined by himself. That positive affect and satisfaction with life of the individual is high means that his subjective wellbeing is good as well (Diener et al., 1985; Diener et al., 2002).

As satisfaction with life includes overall cognitive evaluations of the individual about whether he is satisfied with certain life spaces such as family, friends, living environments, etc. or his life as a whole (Pavot and Diener, 1993; Diener et al., 1999) it might be affected by the stress and motivation level. In this respect, satisfaction with life may be described as an important element of happiness, dissatisfaction with life may be described as a symptom of stress (Diener, 2000) the optimism may be described as a source of motivation for coping with difficulties and problems (Ewen, 2003).

It can be said that satisfaction with life is a factor which enables the individual to look positively to the events he experiences, to be optimistic and therefore it increases his coping with stress and motivation. According to Harju and Bolen (1998) optimism is an important characteristic which mediates the formation of wellbeing by affecting motivation and coping behaviour. The stress reactions of the people who have different characteristics to the events they experience might be different.

Seen especially in A type people who feel time pressure, who are hasty, perfectionist, selfish and competitive (Eren, 2015) stress causes various organizational and individual outcomes. Organizational outcomes of stress might be in the form of low performance, dissatisfaction and absence. Individual outcomes can be listed as physical, psychological and behavioural. These might cause that the individual experiences physical, emotional, mental and relational problems (Ergeneli, 2017). The individual tries to cope with stress to avoid such negative circumstances.

Coping with stress can be described as the psychologic and physiologic effort made by the individual to control the situation, tolerate the situation, reduce or minimize the effects thereof when he encounters a situation which causes stress (Watson et al., 2008). An outcome of social conditioning and experience in general, motivation is a force which initiates necessary behaviours to fulfil a need. This force might be an event which comforts the individual or causes disappointment (Kim, 1996).

People may experience some negative emotions such as sadness, failure and agony throughout their lives. To cope with such negative emotions, the individual needs to calm down, relax and most importantly overcome these negative emotions without suffering a damage (Deniz et al., 2012). For that reason, it can be said that coping skills have a significant role for changing factors which reduce satisfaction with life and increasing the individual's satisfaction with life will increase the motivation.

Important concepts for motivation include instinct and need. Instinct pushes the individual towards behaviour for fulfilling the needs. For that reason, motivation starts with individual's needing certain things. Eliminating the imbalances between needs and satisfaction reduces neural tensions and directs the individual to life and work happiness (Sabuncuoglu and Vergiliel-Tüz, 2013). However, long term stressful life damages the physical, emotional and psychologic wellbeing of the individual. For that reason, people use two types of strategies for coping with stress when they encounter stressful and difficult situations. First one is the problem oriented coping strategy in which the individual is active to overcome the current situation. Second one is the emotion oriented coping strategy which focuses on coping with the emotions related to the situation rather than the situation itself (Hefferon and Boniwell, 2011).

It can be said that the relationship between satisfaction with life, motivation and coping with stress is theoretically supported by Glasser (1975) reality therapy and control/choice theory, Deci and Ryan (1985) selfdetermination theory, Ellis (1957) ABC theory and positive psychology. The relationships between these theories and analysed variables can be summarized as follows: William Glasser's reality therapy is interested in whether behaviours fulfil basic needs without harming themselves and others. According to this view, two basic needs of humans are relationality (love) and respect (Corey, 2001). In Deci and Ryan (2000) self-determination theory, it is emphasized that the individual will be able to realize the most productive development and wellbeing when his psychological needs are fulfilled. Created by Ellis (1957) the ABC model (event-situation, belief-interpretation, emotional-behavioural-cognitive outcome) explains the relationship between thoughts, emotions and behaviours. For example, the events that a student experiences might cause that his satisfaction with life decreases and feels depressing emotions such as lack of motivation, stress and exhaustion. Such negative emotions might affect the individual's education life, happiness and health negatively. In addition, the fact that students who will constitute the labour of countries in the future have problems might cause undesired outcomes socially and economically. The aim of positive psychology is to find how to change the emphasis regarding the wrongs in life and what the good things are to replace them (Luthans, 2002). It is a concept related to revealing strengths of people rather than their 
weaknesses, improving their positive traits and having a life which includes positive experiences (Seligman and Csikszentmihalyi, 2000). Based on all the above mentioned theories and approaches, it can be said that this study is within the scope of positive psychology as it aims to reveal the strengths of the individual such as satisfaction with life, coping with stress and motivation and that the individual acquires positive experiences. In addition, it can be said that the humans will be fine and happy when their needs such as love and respect are met and their satisfaction with life and motivation increase.

The way people evaluate and interpret the events in their lives is an important element which affects coping with stress (Baltaş and Baltaş, 1998). It is verified by some researchers that satisfaction with life and stress, satisfaction with life and motivation, stress and motivation are correlated. For example, Eryllmaz (2014) exhibited the relationship between stress, coping, characteristics and subjective wellbeing in the model he developed based on the views of Lazarus and Folkman (1984). Chow (2005) expressed that some variables such as age, stress level, physical health, lifestyle and characteristics play a role as the determinants of satisfaction with life. Argyle (1994) suggested that satisfaction with life is a subdimension of happiness and low levels of depression and stress will affect satisfaction with life positively. Demir-Güdül (2015) determined in their study that students with the lowest satisfaction with life are the students with low motivation. In addition, researchers stated that excessive stress might cause distraction, low motivation, absence, feeling down, psychologic exhaustion and various disorders (DeFrank and Ivancevich, 1998; Hannigan et al., 2004).

Diener (2000) stated that cultural and social factors affect subjective wellbeing in some ways. In a study conducted on university students in 42 countries, Diener stated that the order of importance is satisfaction with life, happiness and money for the students in Turkey. For that reason, it can be said that satisfaction with life is important for the university students in Turkey and plays a determining role in some of the problems they have. Thinking that university students' satisfaction with life is important caused that the researches on this matter has increased in recent years (Yetim, 2003; Kümbül-Güler and Emeç, 2006; Gündoğar et al., 2007; Tuzgöl, 2007;2010; Ceçen, 2008; Sahranç, 2008; Ozgur et al., 2010; Aydıner, 2011; Ergin et al., 2011; Civitçi, 2012; Deniz et al., 2012; Kabasakal and Uz-Baş, 2013; Recepoğlu, 2013; Uğurlu, 2013; Ardahan, 2014; Gülcan and Nedim-Bal, 2014; Özgüngör, 2014; Demir-Güdül, 2015; Ertekin-Pınar et al., 2015; Özdemir and Dilekmen, 2016; Bakan and Güler, 2017; Elkin, 2017; Hırlak et al., 2017; Yıldız and Karadaş, 2017). In literature review, although there are studies on subjects such as stress and satisfaction with life (Civitci, 2015; Kaya et al., 2015; Coccia and Darling, 2016) academic stress, satisfaction with life and achievement motivation (Karaman et al., 2018) among university students; it is seen that the relationships between satisfaction with life and coping (Deniz, 2006; Odacı and Cıkrıkçı, 2012) satisfaction with life and motivation (Demir-Güdül, 2015) coping and motivation are investigated in a limited numbed of studies. In addition, studies which investigate the intermediary role of ways of coping with stress in the relationship between the satisfaction with life and motivation of university students could not be found in the literature review. For that reason, it is thought that the research will provide important contributions to the literature.

\section{Method}

\subsection{Study Group}

Study group of the research consists of students studying at Bartın University Faculty of Engineering in the spring semester of 2016-2017 academic year. The study sample consists of 568 university students who were included in the research by simple random sampling. Data collection tools were implemented to volunteering students in the classroom environment. In the study group, $112(19.7 \%)$ of the students are female and $456(80.3 \%)$ are male.

\subsection{Data Collection Tools}

Study data was collected using three Likert type measurement instruments. These are Ways of Coping Scale, Adult Motivation Scale and Satisfaction with Life Scale.

In the research, ways of coping scale was used with the purpose of determining the behaviours, thoughts and attitudes of individuals against stressful situations. The scale was developed by Folkman et al. (1986) and adapted to Turkish by Senol-Durak et al. (2011). There are 7 subdimensions of the scale; Planful Problem Solving, Keep to Self, Seeking Social Support, Escape-Avoidance, Accepting Responsibility, Refuge in Fate and Refuge in Supernatural Forces. In the implementation of the scale on university students and adults, it was found that reliability and item total correlation of all subscales of the Ways of Coping Scale were found at acceptable levels by means of internal consistency. It is calculated as $\mathrm{x}^{2}(413, \mathrm{~N}=485)=654.442, \mathrm{p}=.000 ;\left(\mathrm{x}^{2} / \mathrm{df}=1.497\right)$, RMSEA $=$ $.04, \mathrm{SRMR}=.05, \mathrm{IFI}=.94, \mathrm{TLI}=.93, \mathrm{CFI}=.94$. for the student sample; $\mathrm{x}^{2}(413, \mathrm{~N}=416)=679.794, \mathrm{p}=.000$; $\left(\mathrm{x}^{2} / \mathrm{df}=1.646\right), \mathrm{RMSEA}=.04, \mathrm{SRMR}=.05, \mathrm{IFI}=.93, \mathrm{TLI}=.92, \mathrm{CFI}=.93$ for the adult sample. In this study, it was seen that the internal consistency coefficients (Cronbach's Alpha) calculated for the subdimensions of the scale varied between .54 and .77 and it is .83 for the entire scale.

Adult motivation scale was developed by Tulunay-Ateş and İhtiyaroğlu (2019). The scale consists of 2 parts as internal and external motivation scale and it can be implemented on individuals who are 20-60 years old. Internal motivation dimension of the scale consists of 13 questions and its reliability value is 0,92 . External motivation dimension consists of 8 questions and its reliability value is 0,82 . It is seen that the entire scale consists of 21 items and its reliability value is 0,94 and two components together explain $47.95 \%$ of total variance. According to the confirmatory factor analysis study results; fit indexes in relation to the suggested model were calculated as GFI (0.85), CFI (0.96), NFI (0.91), RMSEA (0.06), CFI (0.96), AGFI (0.82), SRMR (0.06). In this study, it was seen that the internal consistency coefficient (Cronbach's Alpha) of the scale is .89 for internal motivation subdimension, . .74 for external motivation and .89 for the entire scale.

Satisfaction with life scale used in the research was developed by Diener et al. (1985). The scale was adapted to Turkish by Durak et al. (2010). In the adaptation study conducted on university students by the researchers $(\mathrm{n}=$ $547)$; it was found that average score obtained from the scale is 21.91 , standard deviation is 6.18 , internal 
consistency of the scale is .81 and item total scale correlation of the items varied between .55 and .63 . In this study, it was seen that the internal consistency coefficient (Cronbach's Alpha) of the scale is .83.

\subsection{Data Analysis}

In the data analysis; descriptive statistics of variables and correlations thereof were investigated and t-test was conducted for independent samples to determine whether gender varies according to motivation, ways of coping with stress and satisfaction with life. In addition, Structural Equation Modelling (SEM) was done to test the model established in relation to the relationships between stress, motivation and satisfaction with life. LISREL 9.30 and SPSS 24 programs were used for analyses.

The most typical characteristic of SEM studies is that they are based on a theory created by the researcher or they question a theoretical structure which existed before. For that reason, the relation pattern between the variables is identified by exhibiting this theoretical framework in the first phase and it is tested whether the data verifies this theoretical structure (Simşek, 2007). SEM models which include latent and observed variables enable researchers to determine the direct and indirect impacts between the variables (Çelik and Yılmaz, 2013). SEM consists of two parts. These are measurement model and structural model (Cited by Cokluk et al. (2012)).

Before data analysis, lost data was removed and erroneous data was checked and corrected. In addition, outliers with single variable were checked. For this purpose, among calculated $\mathrm{z}$ values, the ones above \pm 3.00 were excluded from the analysis. For that reason, the data of 22 participants that were incomplete or determined to be outlier were excluded and analyses were realized with the data of 568 participants. As SEM is a multi-variable analysis, the sterility of the data from multi-variable extreme values was tested by calculating Mahalanobis distance and it was determined that there are not multi-variable outliers in the data.

In this research; arithmetic average, median and mode values were examined on SPSS and Lisrel programs to test the normal distribution of the data before structural model analysis. When the findings on normal distribution of data obtained in the study are examined; it was seen that arithmetic average, median and mode values calculated for the entire scale were (3.24; 3.22; 3.29) respectively for coping with stress dimension, (3.88; 3.95; 3.86) respectively for motivation dimension and $(4.37 ; 4.40 ; 4.00)$ respectively for satisfaction with life dimension. As related values are close to each other, it is thought that the data has normal distribution. In addition, this thought is also supported as a result of examining the skewness and kurtosis coefficients, histogram, normal Q-Q plot and non-biased Q-Q plot. After the normality of the data is tested, it was decided to make parametric test and first the reliability of the scales was analysed. Secondly; t-test was conducted to determine whether students' ways of coping with stress, motivation and satisfaction with life vary significantly according to gender. Thirdly; correlation, mean and standard deviation values between the variables were calculated and then it was proceeded with structural equation model after measurement model is analysed and verified. In this stage, the theoretical model established in relation to the relationship between ways of coping with stress, motivation and satisfaction with life was tested and verified. Lastly; analysis was conducted in relation to the intermediary role of ways of coping with stress in the relationship between satisfaction with life and motivation. Results were presented in order accordingly.

\section{Results}

3.1. Students' Ways of Coping with Stress, Motivation and Satisfaction with Life Levels According to Genders

The results of the t-test conducted to determine the students' ways of coping with stress, motivation and satisfaction with life according to their genders are shown in Table 1.

Table-1. Students' Average Scores in Relation to Their Ways of Coping with Stress, Motivation and Satisfaction with Life According to Their Genders and T-Test Results

\begin{tabular}{|c|c|c|c|c|c|c|c|}
\hline & Gender & $\mathbf{N}$ & $\overline{\mathrm{X}}$ & s.s. & sd & $\bar{t}$ & $\bar{p}$ \\
\hline \multirow{2}{*}{$\begin{array}{l}\text { Ways of coping with } \\
\text { Stress }\end{array}$} & Female & 112 & 3.18 & 0.38 & \multirow{2}{*}{566} & \multirow{2}{*}{1.633} & \multirow{2}{*}{0.103} \\
\hline & Male & 456 & 3.25 & 0.47 & & & \\
\hline \multirow{2}{*}{ Motivation } & Female & 112 & 3.91 & 0.50 & \multirow{2}{*}{566} & \multirow{2}{*}{-.554} & \multirow{2}{*}{0.580} \\
\hline & Male & 456 & 3.88 & 0.57 & & & \\
\hline \multirow{2}{*}{ Life satisfaction } & Female & 112 & 4.43 & 1.28 & \multirow{2}{*}{566} & \multirow{2}{*}{-.572} & \multirow{2}{*}{0.568} \\
\hline & Male & 456 & 4.35 & 1.36 & & & \\
\hline
\end{tabular}

In Table 1, it is seen that the average of men is higher than women in ways of coping with stress, but the average of women is higher than men in motivation and satisfaction with life. However, so significant difference was seen between the female students' average scores of ways of coping with stress, motivation and satisfaction with life and the male students' average scores $\left[\mathrm{t}_{(566)}=1.633, .-554, .-572, \mathrm{p}>.05\right]$. In that case, it can be said that the students' ways of coping with stress, motivation and satisfaction with life do not vary significantly according to their genders.

Before the analyses in relation to structural models created in the research; item parcelling method was applied for the latent variable of satisfaction with life and observed variables were shaped. The parcelling decision in relation to these scales was made with the purpose of meeting the likelihood assumptions and reducing the number of parameters calculated in the model (Hagtvet and Nasser, 2004). Exploratory factor analysis was conducted for item parcelling and items of each scale were divided into two parcels as pairs with the lowest and highest factor load according to their factor loads. Thus, 3 latent variables and 11 observed variables were obtained in total. Correlation, average and standard deviation values between variables were calculated and shown in Table 2 and the measurement model created was shown in Figure 1. 
Table-2. Correlation, Average and Standard Deviation Values Between Variables

\begin{tabular}{|c|c|c|c|c|c|c|c|c|c|c|c|c|c|}
\hline Variable & $\overline{\mathbf{X}}$ & sd & 1 & 2 & 3 & 4 & 5 & 6 & 7 & 8 & 9 & 10 & 11 \\
\hline \multicolumn{14}{|l|}{ Motivation } \\
\hline 1.Intrinsic motivation & 3.98 & 0.62 & - & & & & & & & & & & \\
\hline 2.Extrinsic motivation & 3.72 & 0.61 & $.576 * *$ & - & & & & & & & & & \\
\hline \multicolumn{14}{|l|}{$\begin{array}{l}\text { Ways of coping with } \\
\text { stress }\end{array}$} \\
\hline $\begin{array}{l}\text { 3.Planful problem } \\
\text { solving }\end{array}$ & 3.78 & 0.63 & $.460^{* * *}$ & $.321 * *$ & - & & & & & & & & \\
\hline 4. Keep to self & 3.32 & 0.78 & .081 & $.100^{*}$ & $.184 * *$ & - & & & & & & & \\
\hline $\begin{array}{l}\text { 5. Seeking social } \\
\text { support }\end{array}$ & 3.27 & 0.75 & $.106^{*}$ & $.355^{* *}$ & $.354^{* * *}$ & -.058 & - & & & & & & \\
\hline 6. Escape-avoidance & 3.24 & 0.68 & $.085^{*}$ & $.185^{* *}$ & $.318^{* * *}$ & $.378 * *$ & $.279^{* *}$ & - & & & & & \\
\hline $\begin{array}{l}\text { 7.Accepting } \\
\text { responsibility }\end{array}$ & 2.88 & 0.72 & $-.104 *$ & $.114^{* * *}$ & -072 & $.234^{* *}$ & $.218^{* * *}$ & $.290 * *$ & - & & & & \\
\hline 8. Refuge in fate & 3.41 & 0.84 & .076 & $.193 * *$ & $261 * *$ & $.273 * *$ & $.290 * *$ & $.390 * *$ & $.198 * *$ & - & & & \\
\hline $\begin{array}{l}\text { 9. Refuge in } \\
\text { supernatural forces }\end{array}$ & 2.51 & 1.02 & $\begin{array}{c}- \\
.162^{*} * \\
\end{array}$ & .074 & -056 & $.286^{* *}$ & $.286^{* *}$ & $.453 * *$ & $.379^{* *}$ & $.374 * *$ & - & & \\
\hline \multicolumn{14}{|l|}{ Life satisfaction } \\
\hline 10. Life satisfaction 1 & 4.32 & 1.48 & $.159 * *$ & $.104 *$ & $.204^{* * *}$ & -.033 & $.171^{* *}$ & $.088^{*}$ & $-.105^{*}$ & $.143 * *$ & .064 & - & \\
\hline 11. Life satisfaction 2 & 4.40 & 1.40 & $.161 * *$ & $.133 * *$ & $.185^{* *}$ & -.025 & $.178^{* *}$ & .055 & $-.092^{*}$ & $.112^{* *}$ & .075 & $.764 * *$ & \\
\hline
\end{tabular}
*p<0.05** $\mathrm{p}<0.01$

Source: Author's field work

According to Table 2; internal motivation is positively correlated with external motivation, planful problem solving, seeking social support, escape-avoidance, satisfaction with life 1 and satisfaction with life 2 and it is negatively correlated with accepting responsibility and refuge in supernatural forces. External motivation is positively correlated with planful problem solving, keep to self, seeking social support, escape-avoidance, accepting responsibility, refuge in fate, satisfaction with life 1 and satisfaction with life 2. Planful problem solving is positively correlated with keep to self, seeking social support, escape-avoidance, refuge in fate, satisfaction with life 1 and satisfaction with life 2 . Keep to self is positively correlated with escape-avoidance, accepting responsibility, refuge in fate and refuge in supernatural forces. Seeking social support is positively correlated with escapeavoidance, accepting responsibility, refuge in fate, refuge in supernatural forces, satisfaction with life 1 and satisfaction with life 2 . Escape-avoidance is positively correlated with accepting responsibility, refuge in fate, refuge in supernatural forces, satisfaction with life 1 and satisfaction with life 2. Accepting responsibility is positively correlated with refuge in fate and refuge in supernatural forces and negatively correlated with satisfaction with life 1 and satisfaction with life 2 . Refuge in fate is positively correlated with refuge in supernatural forces, satisfaction with life 1 and satisfaction with life 2 . Satisfaction with life 1 is positively correlated with satisfaction with life 2 .

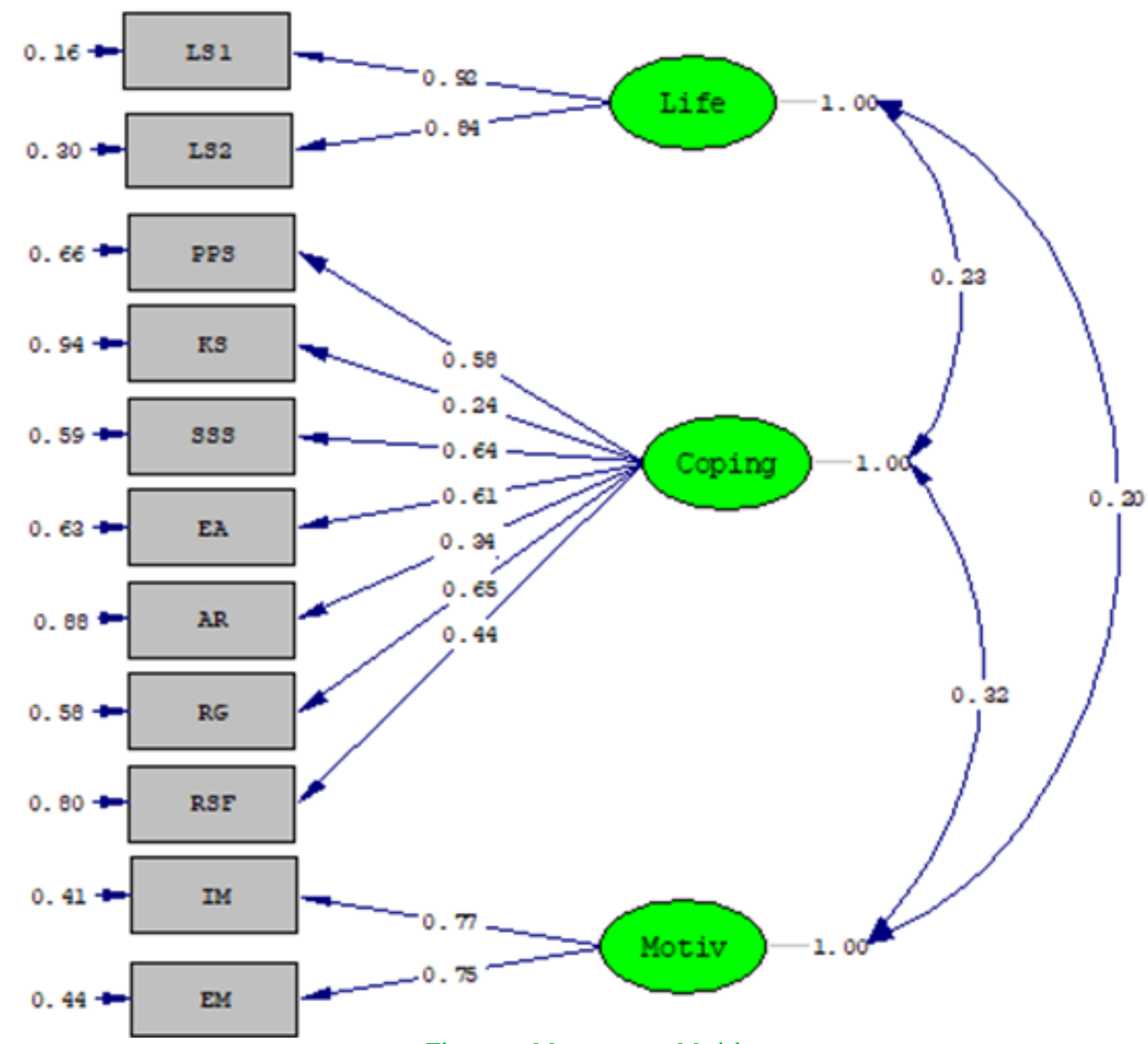

Source: Author's field work

Figure-1. Measurement Model 
In the measurement model, it is seen that validity coefficients of all dimensions varied between $(.24-.92)$, although KS dimension is low, it is valid in general ( $r>.30)$, error variances are not high. In addition, it is seen that $\mathrm{t}$ values varied between (5.30-13.95) $(\mathrm{t}>2,56)$. When the fit indexes of measurement model are examined $\left(\mathrm{X}^{2}=\right.$ 186.68; $\left.\mathrm{sd}=52 ; \mathrm{X}^{2} / \mathrm{sd}=3.59 ; \mathrm{RMSEA}=.08 ; \mathrm{RMR}=.08 ; \mathrm{CFI}=.79 ; \mathrm{GFI}=.99 ; \mathrm{AGFI}=.98\right)$, it is seen that values are high in general. According to the values obtained, it can be said that the fit indexes of the measurement model is on good level (Hu and Bentler, 1999).

After the measurement model is examined, the direct relationship between satisfaction with life and motivation was tested and it was seen that the path coefficient which shows the relationship between them is 0.21. The structural model which was created is given in Figure 2.

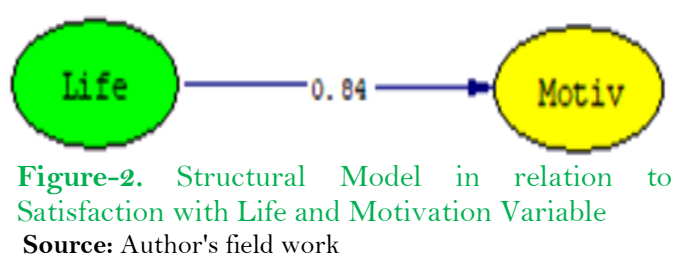

After the structural model is examined, the model was tested by adding the ways of coping with stress as intermediary variable to the model between satisfaction with life and motivation. The model which was obtained is as shown in Figure 3.

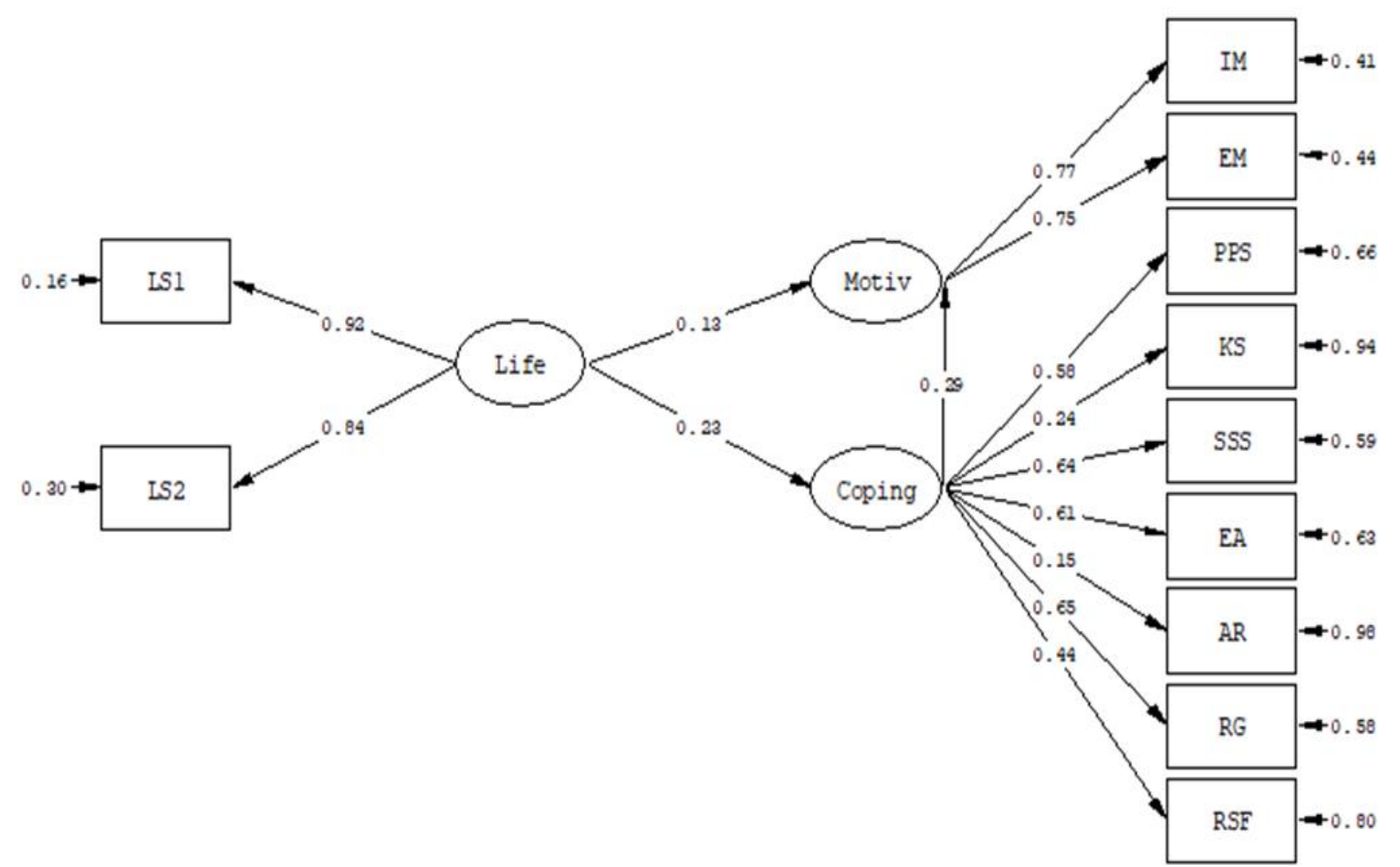

Figure-3. Intermediary Role of Ways of Coping with Stress in the Relationship Between Satisfaction with Life and Motivation

Source: Author's field work

When the fit indexes of the model in Figure 3 are examined $\left(\mathrm{X}^{2}=206.46 ; \mathrm{sd}=52 ; \mathrm{X}^{2} / \mathrm{sd}=3.97\right.$; RMSA $=$ $.08 ; \mathrm{RMR}=.08 ; \mathrm{CFI}=.79 ; \mathrm{GFI}=.99 ; \mathrm{AGFI}=.98)$, it is seen that values are high in general. It was determined that the structural model established according to the values obtained have good fit values and the t-values of the relationships between variables are significant. When the structural model in Figure 2 is examined, it is seen that the impact of satisfaction with life on motivation is .84; when the intermediary model in Figure 3 is examined, it is seen that it decreases to .13. This decrease in path coefficient can be described as an evidence of the intermediary role of ways of coping with stress between satisfaction with life and motivation. However, it can be said that the path added to the model in intermediary test does not contribute in the fit indexes of the model significantly.

\section{Discussion, Conclusion and Recommendations}

In the study conducted, it was concluded that university students' ways of coping with stress, motivation and satisfaction with life do not vary significantly according to gender. In the research, it was also determined that the average of men is higher than women in coping with stress and the average of women is higher than men in motivation and satisfaction with life. When the researches on university students are examined, it is seen that there is no consensus on this matter. For example, there are studies which come to various conclusions that strategies of coping with stress vary according to gender (Savcı and Aysan, 2014) there is no significant relationship between gender and stress level (Durna, 2006) but there is positive relationship with satisfaction with life (Coccia and Darling, 2016) women use emotion oriented coping strategies more than men (Brougham et al., 2009). It can also be said that different conclusions are made in researches on the relationship between gender and satisfaction with life. The researches came to various conclusions that there is no significant difference between genders and satisfaction with life of university students (Bailey and Miller, 1998; Gündoğar et al., 2007; Zullig et al., 2009; Ozgur et al., 2010; Tuzgöl-Dost, 2010; Ergin et al., 2011; Tümkaya, 2011; Kabasakal and Uz-Baş, 2013; Bakan and Güler, 2017; Hırlak et al., 2017) gender has no significant impact on satisfaction with life (Chow, 2005) there is difference between genders in terms of satisfaction with life and women are more satisfied with life than men 
(Kümbül-Güler and Emeç, 2006; Tuzgöl, 2007;2010; Aydıner, 2011; Odacı and Cıkrıkçı, 2012; Gülcan and NedimBal, 2014; Kaya et al., 2015; Elkin, 2017). Hassanzadeh and Mahdinejad (2013) found no significant relationship between gender and academic motivation in their research.

The reason why the women's average is low in terms of coping with stress might be the fact that women are more emotional. The reason why men's motivation and satisfaction with life is low might be the fact that Turkish society has a patriarchal nature and the result of the anxiety caused by the fact that men assume more responsibility about work life.

The reason why different conclusions are made in studies in relation to the relationship between gender and satisfaction with life, coping and motivation might be the fact that research group is affected by factors such as social gender perception, culture and economic conditions (Kim, 1996) stated that motivation forces are not universal, they are subjective and their priority and content may change at any time. It can be said that the same applies to satisfaction with life and stress as well. Hence, pointing out the fact that satisfaction with life levels vary among countries in the studies conducted (Tuzgöl-Dost, 2010; Deniz et al., 2012) is an indicator of that.

In the correlation analysis and measurement model in the research; it was seen that there is positive relationship between motivation, ways of coping with stress and satisfaction with life. This result is also supported by some researches (Matheny et al., 2002). As stress control variable can be discussed as coping method (Lazarus and Folkman, 1984) it can be said that the results of the study are also supported by some researches which show that stress control evaluation has a direct and positive impact on satisfaction with life (Sahranç, 2008). In addition, the research results are also supported by some researches which show that there is a negative relationship between satisfaction with life and stress among university students (Bailey and Miller, 1998; Weinstein and Laverghetta, 2009; Civitci, 2015; Kaya et al., 2015; Coccia and Darling, 2016) problem oriented coping strategy predicts satisfaction with life (Odacı and Cıkrıkçı, 2012) satisfaction with life has a positive relation with problem oriented coping (Deniz, 2006). In a limited number of researches which investigate the relationships between satisfaction with life and motivation, it is determined that there is a significant relationship between motivation and satisfaction with life (Demir-Güdül, 2015) and between academic motivation and happiness among university students (Hassanzadeh and Mahdinejad, 2013).

In their study on the intermediary impacts of achievement motivation and control focus in the relationship between academic stress and satisfaction with life, Karaman et al. (2018) identified that there is a positive insignificant relationship between academic stress and achievement motivation, a negative significant relationship between academic stress and satisfaction with life and a positive significant relationship between satisfaction with life and achievement motivation. In addition, they also determined that achievement motivation is not intermediary in the relationship between academic achievement and satisfaction with life. This research result indicates that satisfaction with life not only affects coping with stress, but also be affected by stress.

Lastly, when the fit indexes of the model are examined, it was seen that values are high in general. In the model obtained, it was determined that ways of coping with stress have intermediary impact in the relationship between satisfaction with life and motivation. Based on this research result, it can be said that it is necessary to improve students' skills for coping with stress to increase their motivations. For that reason, university students whose satisfaction with life, coping with stress and motivation levels are low can be identified and preventive and remedial studies can be conducted. The factors which change students' levels of coping with stress and not being able to cope with stress can be investigated. As Ihtiyaroğlu (2018) states, stress, which is a part of daily life and the process of coping with stress effectively can be included in the scope of courses that have suitable contents.

In this research, it can be said that the fact that sample consists of only students studying at Bartın University Faculty of Engineering is the restriction of the research. For that reason, new researches can be conducted at different departments, universities and countries and results can be compared.

\section{References}

Ardahan, F., 2014. Examining the relation between social capital, life satisfaction and academic achievement: School of physical education and sport case. International Journal of Human Sciences, 11(1): 1212-1226.

Argyle, M., 1994. The psychology of happinses. London: Routledge Press.

Aydiner, B.B., 2011. The relationship between sub-dimensions of the life goals with general self-efficacy, life-satisfaction and some variables. Unpublished Master Thesis, Sakarya: Sakarya Unıversity Institute of Educational Sciences.

Bailey, R.C. and C. Miller, 1998. Life satisfaction and life demands in college students. Social Behavior and Personality: An International Journal, 26(1): 51-56. Available at: https://doi.org/10.2224/sbp.1998.26.1.51.

Bakan, İ. and B. Güler, 2017. The effects of emotional intelligence on life satisfaction and academic success and perception differences in the context of demographic characteristic. Karamanoglu Mehmetbey University Journal of Social and Economic Research, 19(33): 111.

Baltaş, A. and Z. Baltaş, 1998. Stress and ways of coping. 18th Edn., Istanbul: Remzi.

Brougham, R.R., C.M. Zail, C.M. Mendoza and J.R. Miller, 2009. Stress, sex differences, and coping strategies among college students. Current Psychology, 28(2): 85-97. Available at: https://doi.org/10.1007/s 12 144-009-9047-0.

Ceçen, A., 2008. Sense of coherence, family sense of coherence and self esteem in predicting life satisfaction among university students. Journal of Theory and Practice in Education, 4(1): 19-30.

Çelik, H.E. and V. Yılmaz, 2013. Structural equation modeling with LISREL 9.1. Ankara: Anı.

Chow, H.P., 2005. Life satisfaction among university students in a Canadian prairie city: A multivariate analysis. Social Indicators Research, $70(2)$ : 139-150. Available at: https://doi.org/10.1007/s1 1205-004-7526-0.

Civitci, A., 2015. Perceived stress and life satisfaction in college students: Belonging and extracurricular participation as moderators. Procedia-Social and Behavioral Sciences, 205: 271-281. Available at: https://doi.org/10.1016/j.sbspro.2015.09.077.

Civitçi, A., 2012. The relationships between global life satisfaction and psychological needs in university students. ÇÜ Journal of Social Sciences Institute, 21(2): 321-336.

Coccia, C. and C.A. Darling, 2016. Having the time of their life: College student stress, dating and satisfaction with life. Stress and Health, 32(1): 28-35. Available at: https://doi.org/10.1002/smi.2575.

Cokluk, Ö., G. Sekercioğlu and Ş. Büyüköztürk, 2012. SPSS and LISREL aplications for social sciences multivariate statistics (2th Edn.). Ankara: Pegem.

Corey, G., 2001. Theory and practice of counseling and psychotherapy. 6th Edn., Wadsworth: Brooks Cole, Thompson Learning.

Deci, E.L. and R.M. Ryan, 1985. Intrinsic motivation and self-determination in human behavior. New York: Plenum.

Deci, E.L. and R.M. Ryan, 2000. The" what" and" why" of goal pursuits: Human needs and the self-determination of behavior. Psychological Inquiry, 11(4): 227-268. Available at: https://doi.org/10.1207/s15327965pli1104_01. 
DeFrank, R.S. and J.M. Ivancevich, 1998. Stress on the job: An executive update. Academy of Management Perspectives, 12(3): 55-66. Available at: https://doi.org/10.5465/ame.1998.1109050.

Demir-Güdül, M., 2015. The relationship between university students' academic motivation profiles and psychological needs, academic procrastination and life satisfaction. Unpublished Doctoral Thesis, Eskişehir: Anadolu University Educational Sciences Institute.

Deniz, M., 2006. The relationships among coping with stress, life satisfaction, decision-making styles and decision self-esteem: An investigation with Turkish university students. Social Behavior and Personality: An International Journal, 34(9): 1161-1170. Available at: https://doi.org/10.2224/sbp.2006.34.9.1161.

Deniz, M.E., C. Arslan, Z. Özyeşil and M. İzmirli, 2012. Self compassion, life satisfaction, negative and positive affect: A comparison between Turkey and other different countries' university students. Mehmet Akif Ersoy University Journal of Education Faculty, 12(23): $428-446$.

Diener, E., 1984. Subjective well-being. Psychological Bulletin, 95(3): 542-575.

Diener, E., 2000. Subjective well-being. The science of happiness and a proposal for a national index. The American Psychologist, 55(1): 3443. Available at: https://doi.org/10.1037//0003-066x.55.1.34.

Diener, E., R.A. Emmons, R.J. Larsen and S. Griffin, 1985. The satisfaction with life scale. Journal of Personality Assessment, 49(1): 71-75.

Diener, E., R. Lucas, S. Oishi, C. Snyder and S. Lopez, 2002. Handbook of positive psychology. Oxford: University Press.

Diener, E., E.M. Suh, R.E. Lucas and H.L. Smith, 1999. Subjective well-being. Psychological Bulletin, 125(2): $276-302$.

Durak, M., E. Senol-Durak and T. Gencoz, 2010. Psychometric properties of the satisfaction with life scale among Turkish university students, correctional officers, and elderly adults. Social Indicators Research, 99(3): 413-429. Available at: https://doi.org/10.1007/s1 1205-010-9589-4.

Durna, U., 2006. Investigation of stress levels of university students according to some of variables. Journal of Atatürk University Economics and Administrative Sciences Faculty, 20(1): 319-343.

Elkin, N., 2017. General life satisfaction levels and related factors of a school of health sciences of a foundation university. IGUSABDER, 2: $123-141$.

Ellis, A., 1957. Rational psychotherapy and individual psychology. Journal of Individual Psychology, 13(1): 38-44.

Eren, E., 2015. Organizational behavior and manegement psychology. 15th Edn., Ankara: Beta.

Ergeneli, A., 2017. Organizational behavior: Organization and individual. Ankara: Nobel.

Ergin, A., C. Hatipoğlu, A.İ. Bozkurt, M. Bostancı, B.M. Atak, S. Kısaoğlu, S. Parasız, H. Kaygısız, A. Çınarlık and E. Karasu, 2011. Life satisfaction and self-care agency levels of the medical students and infl uencing factors. Pamukkale Medical Journal, 4(3): 144-151.

Ertekin-Pınar, Ş., D. Bilgiç, G. Demirel, M.B. Akyüz, C. Karatepe and D. Sevim, 2015. Relationship between burnout and life satisfaction of university students in the health field. TAF Preventive Medicine Bulletin, 14(4): 284-292. Available at: https://doi.org/10.5455/pmb.1-1417432935.

Eryılmaz, A., 2014. Reference book of happiness. Ankara: Pegem.

Ewen, R.B., 2003. An introduction to theories of personality. 3rd Edn., USA: Lawrence Erlbaum Associates.

Folkman, S., R. Lazarus, C. Dunkel-Schetter, A. DeLongis and R. Gruen, 1986. Dynamics of a stressful encounter: Cognitive appraisal, coping, and encounter outcomes. Journal of Personality and Social Psychology, 50(5): 992-1003. Available at: https://doi.org/10.1037//0022-35 14.50.5.992.

Glasser, W., 1975. Reality therapy. New York: Harper and Row.

Gülcan, A. and P. Nedim-Bal, 2014. Investigating the effect of optimism on happiness and life satisfaction of young adults. Asian Journal of Instruction, 2(1): 41-52.

Gündoğar, D., S. Sallan Gül, E. Uşkun, S. Demirci and D. Keçeci, 2007. Investigation of the predictors of life satisfaction in university students. Journal of Clinical Psychiatry, 10(1): 14-27.

Hagtvet, K.A. and F.M. Nasser, 2004. How well do item parcels represent conceptually defined latent constructs? A two-facet approach. Structural Equation Modeling, 11(2): 168-193. Available at: https://doi.org/10.1207/s15328007sem1102_2.

Hannigan, B., D. Edwards and P. Burnard, 2004. Stress and stress management in clinical psychology: Findings from a systematic review. Journal of Mental Health, 13(3): 235-245. Available at: https://doi.org/10.1080/09638230410001700871.

Harju, B.L. and L.M. Bolen, 1998. The effects of optimisin on coping and perceived quality of life of college students. Journal of Social Behavior and Personality, 13(2): 185-200.

Hassanzadeh, R. and G. Mahdinejad, 2013. Relationship between happiness and achievement motivation: A case of university students. Journal of Elementary Education, 23(1): 53-65.

Hefferon, K. and I. Boniwell, 2011. Positive psychology theory, research and applications. London: McGraw-Hill.

Hırlak, B., M. Taşlıyan, E. Fidan and B. Güler, 2017. The relationship between the quality of faculty life, academic self-efficacy and satisfaction with life: A field research on students of faculty of economics and administrative sciences. Journal of social and humanities sciences Research, 4(2): 86-104.

Hu, L.t. and P.M. Bentler, 1999. Cutoff criteria for fit indexes in covariance structure analysis: Conventional criteria vers us new alternatives. Structural Equation Modeling: A Multidisciplinary Journal, 6(1): 1-55. Available at: https://doi.org/10.1080/10705519909540118.

Ihtiyaroğlu, N., 2018. Analysis of relationship between teachers'coping styles with stress and level of organizational commitment. International Online Journal of Educational Sciences, 1O(2): 192-206. Available at: https://doi.org/10.15345/iojes.2018.02.013.

Kabasakal, Z. and A. Uz-Baş, 2013. Problem solving skills of teacher candidates predicting of life satisfaction. Journal of Research in Education and Teaching, 2(1): 27-35.

Karaman, M.A., K.M. Nelson and J. Cavazos Vela, 2018. The mediation effects of achievement motivation and locus of control between academic stress and life satisfaction in undergraduate students. British Journal of Guidance \& Counselling, 46(4): 375-384. Available at: https://doi.org/10.1080/03069885.2017.1346233.

Kaya, C., T.N. Tansey, M. Melekoğlu and O. Çakiroğlu, 2015. Stress and life satisfaction of Turkish college students. College Student Journal, 49(2): 257-261.

Kim, S.H., 1996. 1001 ways to motivate yourself and others. Turtle Press. Available from https://books.google.com.tr/books?isbn=1880336073.

Kümbül-Güler, B. and H. Emeç, 2006. Effect of optimism of life satisfaction and academic achievement. Journal of Dokuz Eylül University Economics and Administrative Sciences Faculty, 21(2): 129-149.

Lazarus, R.S. and S. Folkman, 1984. Stress, appraisal and coping. New York: Sipringer.

Lu, L., 2000. Gender and conjugal differences in happiness. The Journal of Social Psychology, 140(1): 132-141. Available at: https://doi.org/10.1080/00224540009600451.

Luthans, F., 2002. Positive organizational behavior: Developing and managing psychological strengths. Academy of Management Perspectives, 16(1): 57-72. Available at: https://doi.org/10.5465/ame.2002.6640181.

Matheny, K.B., W.L. Curlette, F. Aysan, A. Herrington, C.A. Gfroerer, D. Thompson and E. Hamarat, 2002. Coping resources, perceiv ed stress, and life satisfaction among Turkish and American university students. International Journal of Stress Management, 9(2): 81-97. Available at: http://dx.doi.org/10.1023/A:1014902719664.

Neugarten, B.L., R.J. Havighurst and S.S. Tobin, 1961. The measurement of life satisfaction. Journal of Gerontology, 16(2): 134-143.

Odacı, H. and Ö. Cukrıkçı, 2012. University students' ways of coping with stress, life satisfaction and subjective well-being. The Online Journal of Counselling and Education, 1(3): 17-130.

Özdemir, M. and M. Dilekmen, 2016. A survey on emotional intelligence and life satisfaction level of education faculty students. Sakarya University Journal of Education, 6(1): 98-1 13. Available at: http://dx.doi.org/10.19126/suje.66890.

Özgüngör, S., 2014. Intimacy and GPA in the relationship between identity and life satisfactions. Turkish Psychological Counseling and Guidance Journal, 5(42): 195-207.

Ozgur, G., A.B. Gumus and B. Durdu, 2010. Life satisfaction of university students at home and dormitory. Journal of Ps ychiatric Nursing, $1(1): 25-33$.

Pavot, W. and E. Diener, 1993. The affective and cognitive context of self-reported measures of subjective well-being. Social Indicators Research, 28(1): 1-20. Available at: https://doi.org/10.1007/bfo 1086714. 
Recepoğlu, E., 2013. Analyzing the relationship between prospective teachers' life satisfaction and attitudes concerning teaching profession. Hacettepe University Journal of Education, 1(Special Issue): 311-326.

Sabuncuoglu, Z. and M. Vergiliel-Tüz, 2013. Organizational behaviour. Bursa: Alfa Aktüel.

Sahranç, Ü., 2008. A state flow model: The relationships among stres control, general self-efficacy, state anxiety, life satisfaction and state flow. The Journal of SAU Education Faculty, $0(16): 122-144$.

Savcı, M. and F. Aysan, 2014. The relationship between the perceived stress level and the stress coping strategies in university students. International Journal of Turkish Education Sciences, 2(3): 44-56.

Seligman, M.E.P. and M. Csikszentmihalyi, 2000. Pozitive psychology. American Pssychologist, 55(3): 5-14.

Senol-Durak, E., M. Durak and F.Ö. Elagöz, 2011. Testing the psychometric properties of the ways of coping questionnaire (WCQ) in Turkish university students and community samples. Clinical Psychology \& Psychotherapy, 18(2): 172-185. Available at: https://doi.org/10.1002/cpp.677.

Simșek, Ö.F., 2007. Introduction to structural equation modeling; basic principles and LISREL applications. Ankara: Ekinoks.

Tinto, V., 1975. Dropout from higher education: A theoretical synthesis of recent research. Review of Educational Research, 45(1): 89-125. Available at: https://doi.org/10.2307/1170024.

Tulunay-Ateş, Ö. and N. İhtiyaroğlu, 2019. Adult motivation scale: A scale development study. Kastamonu Education Journal, 27((2), (in press)).

Tümkaya, S., 2011. Humor styles and socio-demographic variables as predictors of subjective well-being of Turkish university students. Education and Science, 36(160): 158-170.

Tuzgöl-Dost, M., 2010. An examination of subjective well-being and life satisfaction of students attending to universities in South Africa and Turkey. Education and Science, 35(158): 75-89.

Tuzgöl, D.M., 2007. Examining life satisfaction levels of university students in terms of some variables. Pamukkale University Journal of Education, 2: 132-142

Uğurlu, O., 2013. The mediator effects of positive and negative affectivity on the relationship between optimism-pessimism and satisfaction with life. H. U. Journal of Education, 28(2): 497-504.

Watson, J.M., H.L. Logan and S.L. Tomar, 2008. The influence of active coping and perceived stress on health disparities in a multi-ethnic low income sample. BMC Public Health, 8(1): 1-9. Available at: https://doi.org/10.1186/1471-2458-8-41.

Weinstein, L. and A. Laverghetta, 2009. College student stress and satisfaction with life. College Student Journal, 43(4): $1161-1162$.

Yetim, U., 2003. The impacts of individualism/collectivism, self-esteem, and feeling of mastery on life satisfaction among the Turkish university students and academicians. Social Indicators Research, 61(3): 297-317.

Yıldız, M.A. and C. Karadaş, 2017. Multiple mediation of self-esteem and perceived social support in the relationship between loneliness and life satisfaction. Journal of Education and Practice, 8(3): 130-139.

Zullig, K.J., E.S. Huebner and S.M. Pun, 2009. Demographic correlates of domain-based life satisfaction reports of college students. Journal of Happiness Studies, 10(2): 229-238. Available at: https://doi.org/10.1007/s 10902-007-9077-y. 